\title{
The Effect of Problem Based Learning Model on Mathematical Communication Skills and Students' Self-Confidence in Junior High School
}

\author{
Muhammad Febri Rafli \\ Student of Postgraduate School \\ Universitas Negeri Medan \\ Medan, Indonesia \\ febrirafli1@gmail.com
}

\author{
Edi Syahputra, Yusnadi \\ Departement of Basic Education \\ Universitas Negeri Medan \\ Medan, Indonesia
}

\begin{abstract}
The purpose of this study is to determine: (1) the effect of problem based learning model on students 'mathematical communication ability, and (2) the effect of problem based learning model on student self-confidence. This research is quasi experiment of population in this research is all students of class VIII junior high school 2 Tanjung Pura Academic Year 2017/2018 which consist of six classes. The sample was chosen by cluster random sampling of two classes. The selected classes are VIII-2 as the experimental class (31 students) and VIII-1 as the control class (32 students). The instruments used are mathematical communication ability test and self-confidence questionnaire. Data obtained from research instruments were analyzed using two-way anova through SPSS program. The results of this research have shown that: (1) there are significant effect of problem based learning model on students' mathematical communication ability and (2) there is significant effect of problem based learning model on self-confidence of students.
\end{abstract}

Keywords - Problem Based Learning, Mathematical Communication Skill, Self-Confidence

\section{INTRODUCTION}

Mathematics is one component of subjects in schools that have an important role in life. Vassiliou [1] mathematics is recognised as being a subject of great importance both within school and in wider society. Its concepts and processes are essential in a wide range of disciplines, professions and areas of life. In general mathematics has five objectives in mathematics learning. These objectives include: developing mathematical attitudes, gaining proficiency in the use of mathematical language, gaining insight into applications from mathematics in other disciplines [2]. One of the goals of mathematics learning has a purpose so students can communicate well. This is in accordance with the standard of the mathematics learning process formulated by the National Council of Teacher of Mathematics [3], namely: (1) learning to solve problems (mathematical problem solving); (2) learning to reason (mathematical reasoning); (3) learning to communicate (mathematical communication); (4) learning to associate ideas (mathematical connections); and (5) mathematichal representation.
Mathematical communication is one of the mathematical abilities that students must possess. Learn most of the communication and construct their own knowledge. In addition, with communication students can improve vocabulary, develop speaking skills, write ideas systematically and have better learning abilities [4,5]. Mathematical communication has an important role for students in formulating mathematical concepts and strategies, investing students in the completion of exploration and mathematical investigation, and means for students to communicate to obtain information, share ideas and findings [6,7]. However, the results of the study show that many students experience difficulties in mathematics. Arifin, Kartono \& Sutarto [8] that students' mathematical communication skills are still low. students have difficulty identifying and conveying ideas contained in a problem [9]. Through mathematical communication, the teacher can foster student involvement and participation while focusing on the deep conceptual understanding mentioned in the general standard of mathematics. The development of mathematical language needs to be considered so that students understand better basic mathematical concepts $[10,11]$.

Indicators of mathematical communication skills according to the National Council of Teacher of Mathematics [3], can be seen from: (1) Conveying mathematical thinking coherently and clearly to colleagues and others; (2) Using mathematical language correctly to convey; (3) Preparing mathematical ideas through communication; and (4) Analyze and evaluate other mathematical ideas and strategies. According to Nartani, Hidayat \& Sumiyati [12] proposed mathematical communication indicators, namely: (1) Expressing ideas or ideas with mathematical language in oral sentences; (2) Involving actively in discussions about mathematics; (3) Formulating definitions and generalizations about mathematics; and (4) Formulating mathematical definitions using their own language. From the information above, it can be concluded that the mathematical communication skills of junior high school students are measured from four aspects, namely: (1) changing the mathematical situation or ideas into drawings; (2) formulating mathematical ideas into languages and mathematical symbols; (3) changing information from an 
image/table into a language and mathematical symbol; and (4) explaining the procedure for completion.

Learning objectives are also seen from the affective domain. In this case one of the affective domains that students need to have in mathematics learning is students' selfconfidence attitude. Self-confidence can be interpreted as one part of feelings and thoughts about who we really are [13]. In relation to mathematics learning, self-confidence can be built by erasing the impression that mathematics lessons place students as objects by accepting the theory and memorizing formulas. The ease in learning mathematics can make students appreciate and love mathematics $[14,15]$. From the results of other studies indicate that there is an influence between students 'confidence in students' mathematics learning outcomes $[16,17]$.

In fact, students still have problems with confidence. Students always complain that they have no ability, especially in learning mathematics. When learning, students easily give up and complain that learning is difficult. If asked to work on a question in front of the class, students are overly afraid and feel uncertain about the answer $[14,18]$. In mathematics Pierce and Stacey [19] defines mathematical beliefs, as students' perceptions of their ability to achieve good results and their assurance that they can handle difficulties in mathematics. The following indicators of self-confidence include: 1) Confidence in the face of failure and success; 2) Confidence in competing and compared with friends; 3) Knowing your own limitations in facing competition with friends; 4) Knowing your own limitations in dealing with mathematics; 5) Mathematics as something abstract; 6) Mathematics as something very useful; 7) Mathematics as an art, analytical, and rational; and 8) Mathematics as an innate ability.

More specifically, the low mathematical communication skills and self-confidence of students cannot be separated from the teacher's view of the meaning and model of learning. This is in accordance with what was revealed by Slameto [20] that the role of teachers in the teaching and learning process is to encourage, guide, and provide learning facilities for students to achieve goals. One learning model that can be used to answer these problems is a problem based learning model. Rusman [21] suggests that problem based learning is useful to facilitate the success of problem solving, communication, group work and interpersonal skills better than other approaches. The results show that problem-based learning is effective to improve students' mathematical communication skills. When problem solving is used as a context in mathematics, the focus of learning activities is entirely on students, namely the process to understand a mathematical concept and procedure contained in the problem [22,23].

Amalia, Surya, \& Syahputra [24] says that in the use of PBL, students were guided to find their own answers by following the steps of the PBL model. As in other studies problem based learning makes students more creative, dare to make decisions, think rationally and collaborate effectively with their classmates [25]. Problem based learning has an effect on content knowledge which provides greater opportunities for students to learn with more involvement and increase student active participation, motivation and interest among students. This causes students to have a positive attitude towards mathematics and help them to improve their performance for the most part and which will cause long-term memory [26]. The stages of problem based learning model according to Sunaryo [27] there are 5 phases, namely: (a) Phase of student orientation to problems; (b) Organize students to study; (c) Assisting group investigations; (d) Development and procurement of models or drawings; and e) Analyze the problem solving process. According to Trianto [28] problem-based learning consists of five main steps, namely (1) student orientation to the problem; (2) Organizing students to study; (3) Guiding individual or group investigations; (4) Develop and present the work; and (5) Analyze and evaluate the problem solving process. Conclusions can be drawn in this study that the stages of the problem based learning model are: 1) Giving problems to students; 2) Assessing the problem given; 3) Guiding individual or group mastery; 4) Develop and present the work; and 5) Analyze and evaluate the problem solving process.

The expected end result, the problem based learning model can stimulate students to be more confident both in terms of communication verbally and in writing because each student always interacts between the teacher and other students. This is reinforced by the results of research which revealed that students who have high confidence in mathematics will easily answer mathematical communication problems [29]. Of the various issues above, the issues that will be discussed in this study are:

1) Is there an effect of the problem based learning model on students' mathematical communication skills?

2) Is there an effect of the problem based learning model on students' self-confidence?

\section{METHOD}

The type of research used in this study is quasiexperimental. This research was conducted at junior high school 2 Tanjung Pura. The population in this study were all eighth grade students. While sample selection is done by cluster random sampling technique. The sample in this study was class, VIII-2 which was used as an experimental class with total 31 students and class VIII-1 was used as a control group totaling 32 students. This study involved two classes treated differently. The experimental group is treated by applying the problem based learning model, while the control group is treated by applying conventional learning. The instruments used were mathematical communication skill test and self-confidence questionnaire. Data obtained from research instruments were analyzed using two-way ANOVA without interaction through the SPSS program. The following statistical hypothesis is:

- Test the first research hypothesis, namely whether there is an influence on the problem based learning model on students' mathematical communication skills. 
Statistically the hypothesis can be formulated:

$$
\begin{gathered}
\mathrm{H}_{0}: \beta_{11}=\beta_{12} \\
\mathrm{H}_{1}: \beta_{11}>\beta_{12}
\end{gathered}
$$

Information :

$\beta_{11} \quad=$ the influence of the problem based learning model on students' mathematical communication skills

$\beta_{12}=$ the effect of conventional learning on students' mathematical communication skills

- Test the second research hypothesis, namely whether there is an effect of the problem based learning model on students' self-confidence.

Statistically the hypothesis can be formulated:

Information :

$$
\begin{aligned}
& \mathrm{H}_{0}: \beta_{21}=\beta_{22} \\
& \mathrm{H}_{1}: \beta_{21}>\beta_{22}
\end{aligned}
$$

$\beta_{21} \quad=$ the effect of the problem based learning model on students' self-confidence

$\beta_{22}=$ the effect of conventional learning on students' selfconfidence

\section{RESULT AND DISCUSSION}

\section{A. Result}

Description of the results calculation in communication skills mathematically and students' self-confidence can be seen in the table 1 the following:

TABLE 1. Mean And Standard Deviation Kkm Test And Self-Confidence Questionary On Pbl Class And Cl Class

\begin{tabular}{|c|c|c|c|c|}
\hline \multirow{2}{*}{ Class } & \multicolumn{2}{|c|}{ KKM Test } & \multicolumn{2}{c|}{$\begin{array}{c}\text { Self-Confidence } \\
\text { Questionary }\end{array}$} \\
\cline { 2 - 5 } & Mean & $\begin{array}{c}\text { Standar } \\
\text { Deviation }\end{array}$ & Mean & $\begin{array}{c}\text { Standar } \\
\text { Deviation }\end{array}$ \\
\hline $\begin{array}{c}\text { Problem Based } \\
\text { Learning }\end{array}$ & 76,63 & 11,44 & 72,24 & 5,78 \\
\hline $\begin{array}{c}\text { Coventional } \\
\text { Learning }\end{array}$ & 69,34 & 12,91 & 68,18 & 6,96 \\
\hline
\end{tabular}

In table 1 , we can see the average mathematical communication skills and self-confidence of the two groups of students who were taught by the problem based learning model and direct learning. In the problem based learning model, the average mathematical communication ability is 76.63 , while students who get direct learning get an average of mathematical communication skills of 69.34 . While the problem based learning model obtained an average selfconfidence of 72.24, while students who received direct learning gained an average self-confidence of 68.18. The percentage summary results of the achievement of students' mathematical communication skills based on indicators in the experimental class and control class can be seen in the figure 1 and figure 2 :

\section{EKSPERIMENT CLASS}

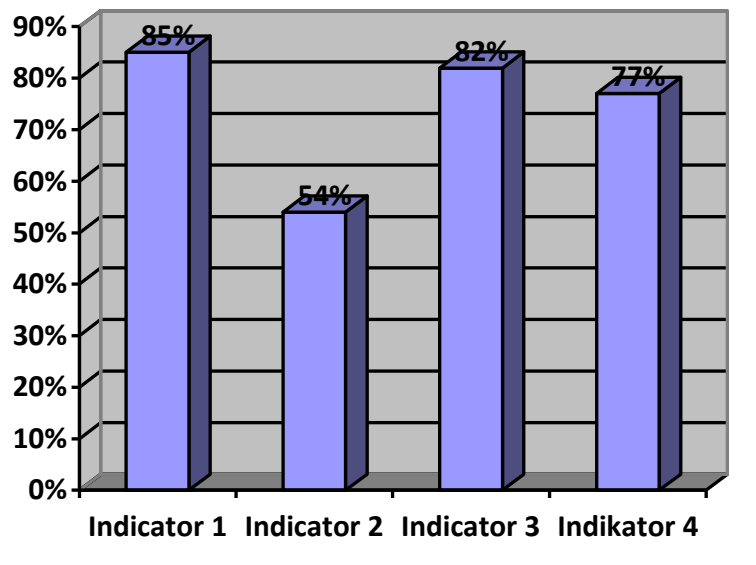

Fig 1. Diagram of Mathematical Communication Skills in Eksperiment Class

Based on figure 1, it can be explained that mathematical communication skills using problem based learning are mostly mastered by indicators 1 and 3 which are changing mathematical situations or ideas into drawings and changing information from an image/table into languages and symbols mathematics.

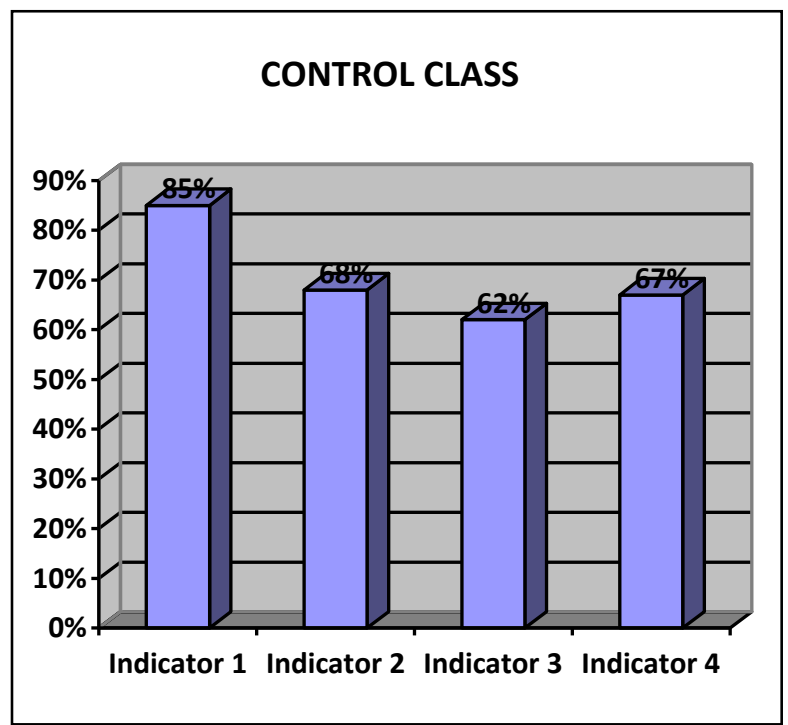

Fig 2. Diagram of Mathematical Communication Skills in Control Class

Based on the figure 2, it can be explained that mathematical communication skills by using ordinary learning are mastered by indicator 1 , namely changing the situation or mathematical ideas into the drawing. The percentage summary results of achievement Self-confidence of students based on indicators in the experimental class and control class can be seen in the figure 3 and figure 4 : 


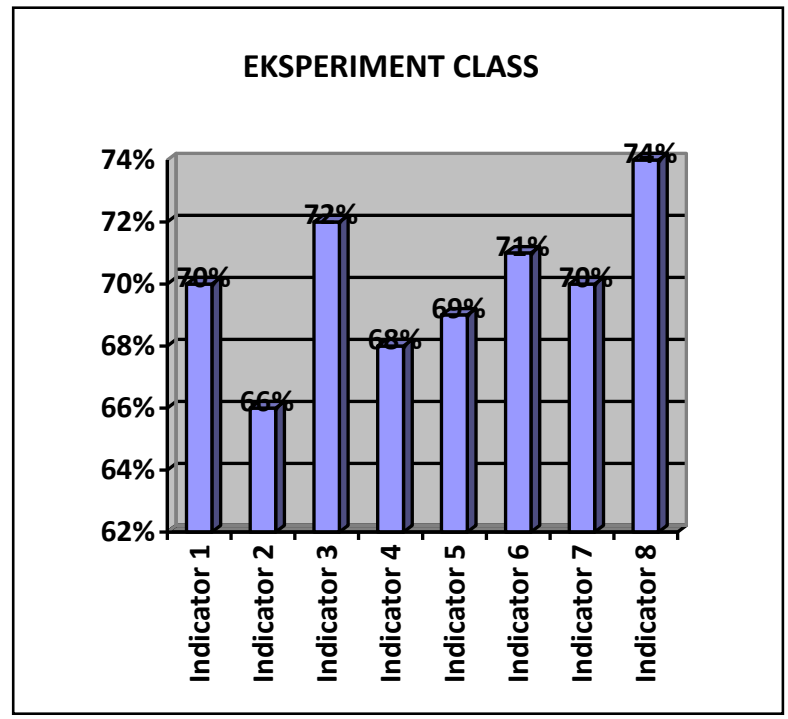

Fig 3. Diagram of Self-Confidence in Eksperiment Class

Based on figure 3, it can be explained that self-confidence taught using problem based learning is mostly controlled by students in the experimental class is an indicator 8, namely mathematics as an innate ability.

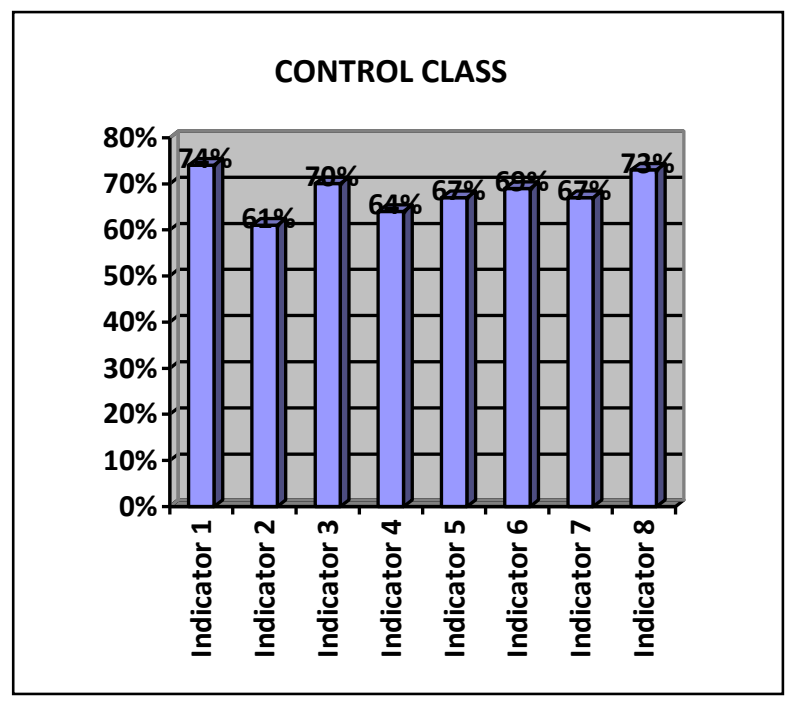

Fig 4. Diagram of Self-Confidence in Control Class

Based on figure 4 , it can be explained that self-confidence by using direct learning is mostly controlled by students in the control class is an indicator 1 that is confident in facing failure and success. To determine the significance of data on statistical testing with a two-way ANOVA test, previously tested for normality and homogeneity of the data. The results of homogeneity and normality of the two classes from the mathematical communication ability test and self-confidence questionnaire indicated that the two sample groups had homogeneous variance and normal data distribution. The following are the results of the two-way ANOVA output calculation with the help of the SPSS version 24.0 statistical software presented in table 2, namely:

TABLE 2. Two Way ANOVA Mathematical Communication Skills
\begin{tabular}{|c|c|c|c|c|c|}
\hline Source & $\begin{array}{c}\text { Type III } \\
\text { Sum of } \\
\text { Squares }\end{array}$ & $\begin{array}{c}\text { D } \\
\text { f }\end{array}$ & $\begin{array}{c}\text { Mean } \\
\text { Square }\end{array}$ & F & Sig. \\
\hline KAM & 2485,944 & 2 & 1242,972 & 12,182 & 0,000 \\
\hline Pembelajaran & 728,651 & 1 & 728,651 & 7,141 & 0,010 \\
\hline $\begin{array}{c}\text { KAM } * \\
\text { Pembelajaran }\end{array}$ & 672,952 & 2 & 336,476 & 3,298 & 0,044 \\
\hline
\end{tabular}

Based on the results of the two-way ANOVA test in table 2 above, the p-value obtained for learning is $0.010<0.05$, that is enough evidence to reject $\mathrm{H}_{0}$ and accept $\mathrm{H}_{1}$. This means that there is an effect of the problem based learning model on students' mathematical communication skills. In other words, the influence of the problem based learning model on mathematical communication skills is better than ordinary learning on mathematical communication skills. The following are the results of the two-way ANOVA output calculation with the help of the SPSS version 24.0 statistical software presented in table 3 , namely

\begin{tabular}{|c|c|c|c|c|c|}
\hline \multicolumn{1}{|c|}{ TABLE 3. Two Way ANOVA Self-Confidence } \\
\hline Source & $\begin{array}{c}\text { Type III } \\
\text { Sum of } \\
\text { Squares }\end{array}$ & $\mathbf{d f}$ & $\begin{array}{c}\text { Mean } \\
\text { Square }\end{array}$ & F & Sig. \\
\hline KAM & 602,736 & 2 & 301,368 & 10,373 & 0,000 \\
\hline Pembelajaran & 148,521 & 1 & 148,521 & 5,112 & 0,028 \\
\hline $\begin{array}{c}\text { KAM * } \\
\text { Pembelajaran }\end{array}$ & 205,936 & 2 & 102,968 & 3,544 & 0,035 \\
\hline
\end{tabular}

Based on the results of the two-way ANOVA test in table 3 above, the p-value obtained for learning is $0.028<0.05$, that is sufficient evidence to reject $\mathrm{H}_{0}$ and accept $\mathrm{H}_{1}$. This means that there is an effect of the problem based learning model on students' self-confidence. In other words, the effect of the problem based learning model on self-confidence is better than ordinary learning on self-confidence.

\section{B. Discussion}

The research findings reveal that the average value of students 'mathematical communication skills taught with the problem based learning model is higher than the average value of students' mathematical communication skills taught by ordinary learning. This proves that the problem based learning model is better than the usual learning done by the teacher in developing students' mathematical communication skills. The results of previous studies explain that mathematical communication skills in the experimental class (model problem based learning) is better than conventional learning by teachers [30,31,32,33]. The learning process presented by the problem based learning model is not just transferring knowledge from the teacher to students, but rather a process that is conditioned by the teacher so that students are active in various ways to build their own knowledge. Kadir and Parman [34] states problems give students attention and challenge students to solve them by way of mathematical methods or communicating their mathematical ideas. Kodariyati \& Astuti [31] explain in PBL models students are more active in learning. In learning using PBL models, students' 
communication skills can be developed in the form of questions at the beginning of learning. The use of student worksheets given to each group also influences the course of the learning process.

The above explanation is supported by learning theory that supports the mathematical communication skills contained in Runtukahu [35] the symbolic stage in the theory of child development from Bruner states that children manipulate symbols or symbols of certain objects. Students are able to use notation without relying on real objects. Other cognitive theories from Piaget say cognitive development as a child process actively builds systems of meaning and understanding of reality through their experiences and interactions [28]. The research findings obtained that the average value of selfconfidence of students who were taught with the problem based learning model was higher than the average value of self-confidence students who were taught with ordinary learning. This proves that the problem based learning model is better than the usual learning done by the teacher in developing students' self-confidence. The results of previous studies also showed that students' self-confidence attitudes were taught with the problem based learning model better than expository learning [36,37,38]. Nurqolbiah [39] the selfconfidence of students who are built through problem-based learning with a scientific approach is superior in showing a positive attitude in dealing with problems.

Self-confidence can also be developed by doing rational and realistic learning in the student environment. This is in line with the problem based learning model which begins to present mathematical problems for students, so students are required to solve problems that are rich in mathematical concepts [40]. Previous research by Cerezo [41] suggests that student responses are very positive by liking problem-based learning. Students are able to work in groups. Students feel problem-based learning makes them challenged to think differently, be open to new ideas and not judgmental, and to be supportive of each other. Rokhmawati, Djatmika, \& Wardana [42] the application of PBL models can also improve students' positive attitudes. This shows that students have developed skills to adapt to the environment and can have self-control. This can be seen from the courage of students appearing to give opinions, the ability to think positively, and the confidence to communicate in class.

\section{IV.CONCLUSION}

Mathematical communication skills of students who are taught using the problem based learning model are better than being taught using conventional learning. This reinforces the results of the analysis which show that there is an influence of the problem based learning model of students' mathematical communication skills. In addition, the students' selfconfidence attitude showed better results in the classroom with the problem based learning model than the classroom with ordinary learning. This study shows that there are positive effects of problem based learning learning models with students' self-confidence. Therefore, the problem based learning model has an effect on students' cognitive and affective abilities in their math class. Recommendations for researchers can develop learning components used in the problem based learning model and the development of computer-based models.

\section{ACKNOWLEDGMENT}

The author would like to thank who have helped write this simple journal. I am really thankful to them.

\section{REFERENCES}

[1] Vassiliou, Androulla. 2011. Mathematics Education in Europe: Common Challenges and National Policies. European Commission: Education, Culture, Multilingualism and Youth.

[2] Heuvel-Panhuizen, M.V.d. \& Wijers, M. 2005. Mathematics standards and curriculain the Netherlands.Journal ZDM, 37(4): 287-307.

[3] CSSU Math Curriculum Committe. 2004. CSSU Math Frameworks. Reston: NCTM.

[4] Ramellan, P., Musdi, E. \& Armiati. 2012. Kemampuan Komunikasi Matematis Dan Pembelajaran Interaktif. Jurnal Pendidikan Matematika, 1(1): 77-82.

[5] Tandililing, E. 2011. The Enhancement of Mathematical Communication and Self Regulated Learning of Senior High School Students ThroughPQ4R Strategy Accompanied by Refutation Text Reading. Proceeding International Seminar and the Fourth National Conference on Mathematics Education Department of Mathematics Education, Yogyakarta State University, 917-928.

[6] Saragih, S. \& Rahmiyana. 2013. Peningkatan Kemampuan Komunikasi Matematis Siswa SMA/MA di Kecamatan Simpang Ulim Melalui Model Pembelajaran Kooperatif TIPE STAD. Jurnal Pendidikan dan Kebudayaan, 19(2): 174-188.

[7] Kurnia, R.N., Setiawani, S. \& Kristiana, A.I. 2015. Analisis Kemampuan Komunikasi Matematis Siswa Kelas VII C SMP Negeri 1 Rogojampi Tahun Pelajaran 2014/2015. Artikel Ilmiah Mahasiswa. 1(1): $1-6$.

[8] Arifin, A.T. Kartono, \& Sutarto, H. 2014. Keefektifan Strategi Pembelajaran React Pada Kemampuan Siswa Kelas VII Aspek Komunikasi Matematis. Jurnal Kreano, 5(1): 91-98.

[9] Agustyaningrum, A. 2011 Implementasi Model Pembelajaran Learning Cycle $5 E$ UntukMeningkatkan Kemampuan Komunikasi Matematis Siswa Kelas IX- BSMP Negeri 2 Sleman. Seminar Nasional Matematika dan Pendidikan Matematika, Yogyakarta, 3 Desember 2011.

[10] Pourdavood, R.G. \& Wachira, P. 2015. Importance of Mathematical Communication and Discourse in Secondary Classrooms. Global Journals Inc, 15(10): 9-20.

[11] Yusra, D.A. \& Saragih, S. 2016. The Profile of Communication Mathematics andStudents' Motivation by Joyful LearningbasedLearning Context Malay Culture. British Journal of Education, Society \& Behavioural Science, 15(4): 1-16.

[12] Nartani, C.I., Hidayat, R.A. \& Sumiyati, Y. 2015. Communication in Mathematics Contextual.International Journal of Innovation and Research in Educational Sciences, 2 (4): 284-287.

[13] Srimadevi, T. \& Saraladevi, K. 2016. Decision Making And Self Confidence On Problem Solving Ability Among Higher Secondary Student Studying Mathematics. International Journal Of Innovative Research In Science, Engineering And Technology, 5(3): 3509-3514..

[14] Hendriana, H. 2014. Membangun Kepercayaan Diri Siswa Melalui Pembelajaran Matematika Humanis. Jurnal Pengajaran MIPA, 19(1): 52-60.

[15] Martyanti, A. 2013. Membangun Self-Confidence SiswaDalam Pembelajaran MatematikaDengan Pendekatan Problem Solving. Prosiding: Seminar Nasional Matematika dan Pendidikan Matematika FMIPA UNYYogyakarta pada tanggal 9 November, 15-22.

[16] Ameliah, I.H., Munawaroh, M. \& Muchyidin, A. 2016. Pengaruh Keingintahuan Dan Rasa Percaya Diri SiswaTerhadap Hasil Belajar 
MatematikaKelas VII MTs Negeri I Kota Cirebon. Jurnal EduMa, 5(1): 9-21.

[17] Hannula, M.S., Maijala, H. \& Pehkonen, E. 2004. Development Of Understanding And Self Confidence In Mathematics; Grades 5-8. Proceeding of The 28th Conference of the International Group of the Psychology of Mathematics Education, 3: 17-24.

[18] Nurdin, M. 2016. Pengaruh Metode Discovery Learning untuk Meningkatkan Representasi Matematis dan Percaya Diri Siswa. Jurnal Pendidikan Universitas Garut, 9(1): 9-22.

[19] Pierce, R. \& Stacey, K. 2004. A framework for monitoring progress and planning teaching towards the effective use of computer algebra systems. International Journal of Computersfor Mathematical Learning. 9: 59-93.

[20] Slameto. 2010. Belajar Dan Faktor-Faktor Yang Mempengaruhi. Bandung: PT Rineka Cipta.

[21] Rusman. 2014. Model - Model Pembelajaran Mengembangkan Profesionalisme Guru. Jakarta: PT. Raja grafindo Persada

[22] Fachrurazi. 2011. Penerapan Pembelajaran Berbasis Masalah Untuk Meningkatkan Kemampuan Berpikir Kritis Dan Komunikasi Matematis Siswa Sekolah Dasar. Jurnal Edisi Khusus, 1: 76-89.

[23] Gijbels, D., Dochy, F., Bossche, P.V.d. \& Segers, M. 2005. Effects of Problem-Based Learning:A Meta-Analysis From the Angle of Assessment. Review of Educational Research, 75 (1), 27-61

[24] Amalia, E., Surya, E. \& Syahputra, E. 2017. The Effectiveness Of Using Problem Based Learning (PBL) In Mathematics Problem Solving Ability For Junior High School Students. International Journal Of Advance Research And Innovative Ideas In Education, 3(2): 3402-3406

[25] Fatade, A.O., Mogari, D. \& Arigbabu, A.A. 2013. Effect Of ProblemBased Learning On SeniorSecondary School Student' Achievements InFurther Mathematics. Acta Didactica Napocensia, 6(3): 27-44.

[26] Padmavathy, R.D. \& Mareesh .K. 2013. Effectiveness of Problem Based Learning In Mathematics. International Multidisciplinary eJournal, 2(1): 45-51.

[27] Sunaryo, Y. 2014. Model Pembelajaran Berbasis Masalah Untuk Meningkatkan Kemampuan Berpikir Kritis Dan Kreatif Matematik Siswa SMA Di Kota Tasikmalaya. Jurnal Pendidikan dan Keguruan, 1(2): 41-51.

[28] Trianto. 2009. Mendesain Model Pembelajaran Inovatif-Progresif. Jakarta: Kencana.

[29] Sidik, A., Ramlah., \& Utami, M.R. 2017. Hubungan Antara SelfConfidence dengan Kemampuan Komunikasi Matematis Siswa SMP. Prosiding Seminar Nasional Matematika dan Pendidikan Matematika (SESIOMADIKA), 222-226.

[30] Sari, L.S.P. \& Rahadi, M. 2014. Pembelajaran Berbasis Masalah Untuk Meningkatkan Kemampuan Komunikasi Matematika Siswa Sekolah Menengah Pertama. Jurnal Pendidikan Matematika, 3(3): 143-150.
[31] Kodariyati, L. \& Astuti, B. 2016. Pengaruh Model PBL Terhadap Kemampuan Komunikasi Dan Pemecahan Masalah Matematika Siswa Kelas V SD. Jurnal Prima Edukasia, 4(1): 93 - 106.

[32] Surya, E., Syahputra, E., \& Juniati, N. 2018. Effect of Problem Based Learning Toward Mathematical Communication Ability and SelfRegulated Learning. Journal of Education and Practice, 9(6): 14-23.

[33] Nurbaiti, S.I., Irawati, R. \& Lichteria P, R. Pengaruh Pendekatan Problem Based Learning Terhadap Kemampuan Komunikasi Matematis Dan Motivasi Belajar Siswa. Jurnal Pena Ilmiah.1(1): 10011010 .

[34] Kadir, J. \& Parman, M.S. 2013. Mathematical Communication Skills of Junior Secondary School Students in Coastal Area. Jurnal Teknologi (Social Sciences),63(2): 77-83.

[35] Runtukahu, J.T. 2014. Pembelajaran Matematika Dasar Bagi Anak Berkesulitan Belajar. Jogjakarta: Ar-Ruzz Media.

[36] Surya, E., Putri, F.A., \& Mukhtar. 2017. Improving Mathematical Problem-Solving Ability andSelf-Confidence of High School Students through Contextual Learning Model. Journal on MathematicsEducation, 8(1), 85-94.

[37] Purwasih, R. 2015. Peningkatan Kemampuan Pemahaman Matematis dan Self-Confidence Siswa MTs di Kota Cimahi Melalui Model Pembelajaran Inkuiri Terbimbing.Jurnal Ilmiah STKIP Siliwangi BandungDIDAKTIK, 9(1): 16-25.

[38] Istiawati, S.N., Mulyono., \& Syahputra, E. 2017. The Effect of Based Learning Problem Model with MacromediaFlash to the Representation Mathematical Ability VII GradeStudents of SMPN 1 Sidamanik.Journal of Education and Practice, 8(23): 127-132.

[39] Nurqolbiah, S. 2016. Peningkatan Kemampuan Pemecahan Masalah, Berpikir Kreatif danSelf-Confidence Siswa Melalui Model Pembelajaran Berbasis Masalah.Jurnal Penelitian Pendidikan dan Pengajaran Matematika, 2(2): 143-158.

[40] Widyatiningtyas, R., Kusumah, Y.S., Sumarmo, U., \& Sabandar, J. 2015. The Impact of Problem-Based Learning Approach to Senior High School Students' Mathematics Critical Thinking Ability.IndoMS Journal Mathematics Education, 6(2): 30-38.

[41] Cerezo, N. 2004. Problem-Based Learning in the Middle School: AResearch Case Study of the Perceptions of At-Risk Females. Research in Middle Level Education (Online), 27(1): 1-13.

[42] Rokhmawati, J.D., Djatmika, E.T. \& Wardana, L. 2016.Implementation of Problem Based Learning Model to Improve Students' Problem Solving Skill and Self-Efficacy (A Study on IX Class Students of SmpMuhammadiyah).IOSR Journal of Research \& Method in Education (IOSR-JRME). 6(3): 51-55. 